\begin{tabular}{lc}
\hline \hline $\begin{array}{l}\text { MINING AND METALLURGY INSTITUTE BOR } \\
\text { UDK: 622 }\end{array}$ & $\begin{array}{l}\text { ISSN: 2334-8836 (Štampano izdanje) } \\
\text { ISSN: 2406-1395 (Online) }\end{array}$ \\
\hline \hline & doi:10.5937/MMEB1504111R \\
UDK: 621.967.2:622(045)=111 & \\
Branislav Rajkovic ${ }^{*}$, Zoran Ilić, Daniela Uroševic ${ }^{* *}$
\end{tabular}

\title{
SELECTION OF THE IMPACT ROLLERS OF BELT CONVEYOR
}

\begin{abstract}
This work gives the methodology of impact rollers calculation on the example of a shuttle belt conveyor for ore T 3506 designed for the needs of the Majdanpek open pit with capacity of $1600 \mathrm{t} / \mathrm{h}$. The analysis was made by calculation according to the manufacturer instructions of the "Rulmeca" company and it includes checking the static and dynamic load on the impact rollers. The technical characteristics of the impact rollers are also given as well as their graphical representation.

Keywords: belt conveyor for ore, impact rollers calculation, technical characteristics
\end{abstract}

\section{INTRODUCTION}

At the loading part of a belt conveyor carrying rollers, besides being subjected to the weight of material and the weight of conveyor belt, are also subjected to the impact load of material falling on a conveyor belt. This impact load has to be taken into account in selecting the carrying rollers on points where the loading of material takes place.

The shuttle belt conveyor for ore T 3506 is placed above the open storage for ore and it is designed in such a way that the loading of material is done via stationary belt conveyor T 3507 and material discharge is done through a drive pulley or take up pulley depending on a conveyor belt direction. During the operation of belt conveyor, it moves translationally in order to fill the open storage for ore in the full length. As a result of translation motion of belt conveyor, the material loading also takes place in the full length of belt conveyor dictating the selection of carrying rollers as impact rollers.
The shuttle belt conveyor for ore T 3506 is made as horizontal one, and carrying rollers are made as the impact rollers placed in troughing sets containing three rollers in each set [1].

\section{TECHNICAL DESCRIPTION OF IMPACT ROLLERS}

Impact rollers consist of a steel roller with diameter lesser than nominal diameter of the roller itself on which rubber rings are fitted which serve for amortization when material falls on the belt.

Impact roller (label PSV4,30F,159NA, 473; manufacturer Rulmeca) belongs to the PSV series of rollers and consists of roller shell, bearing housings, spindle, bearings, sealing and rubber rings. The roller shell is a machined steel pipe for which the bearing housings are welded. The bearing housings are made of steel by deep drawn with subsequent machining so that, along with the roller shell, they make a compact assembly

\footnotetext{
*Mining and Metallurgy Institute Bor, branislav.rajkovic@irmbor.co.rs
} 
providing good balance and concentricity of the assembly parts. The spindle is made of steel, it is machined and deep groove ball bearings with single raw 6206 are fitted on it. Sealing includes the external stone guard, external section and internal section. The sealing prevents the ingress of impurities from outside (dust, sand, water etc.), impurities from inside (rust, condensate) and it also insures the lubrication of the bearings by grease. The rubber rings are fitted on the outer side of roller shell. Total mass of the roller is $12.6 \mathrm{~kg}$. The impact roller sectional view is given in Figure 1.

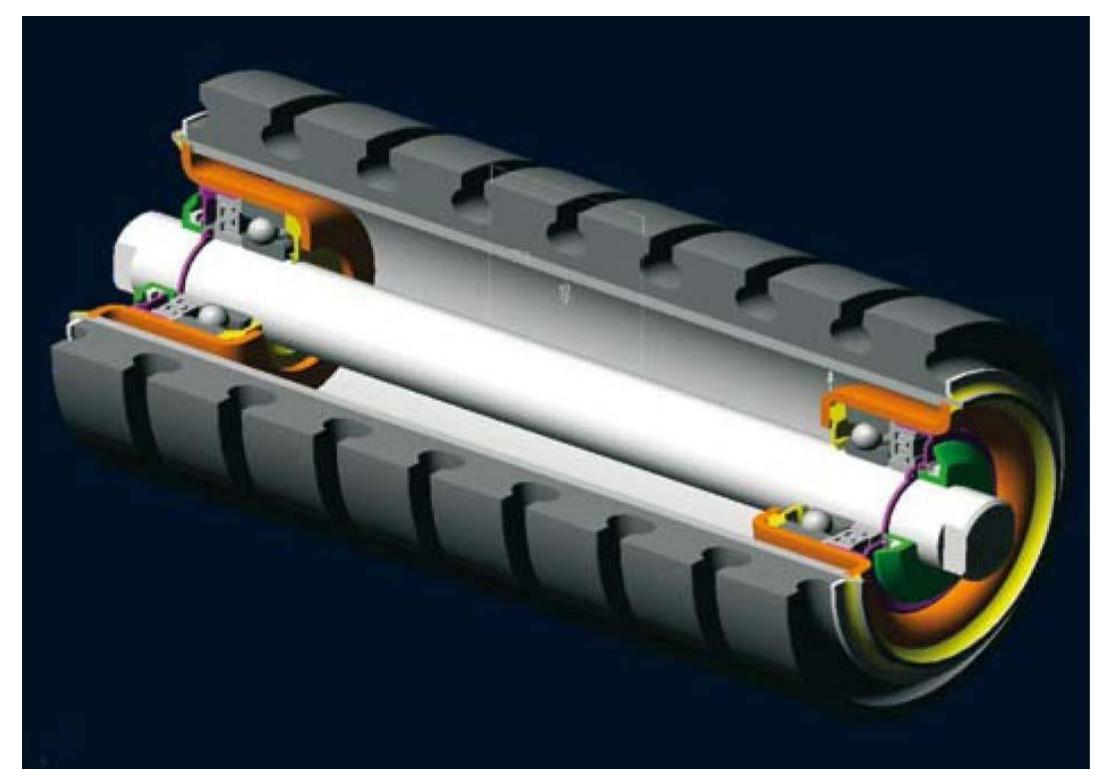

Figure 1 Impact roller sectional view

The impact roller PSV4,30F,159NA, 473 dimensions are given in Figure 2.

$\varnothing e=159 \mathrm{~mm}$

$D=89 \mathrm{~mm}$

$d=30 \mathrm{~mm}$

$d_{1}=30 \mathrm{~mm}$

ch $=22 \mathrm{~mm}$

$A=497 \mathrm{~mm}$

$B=465 \mathrm{~mm}$

$C=473 \mathrm{~mm}$

$E=50 \mathrm{~mm}$

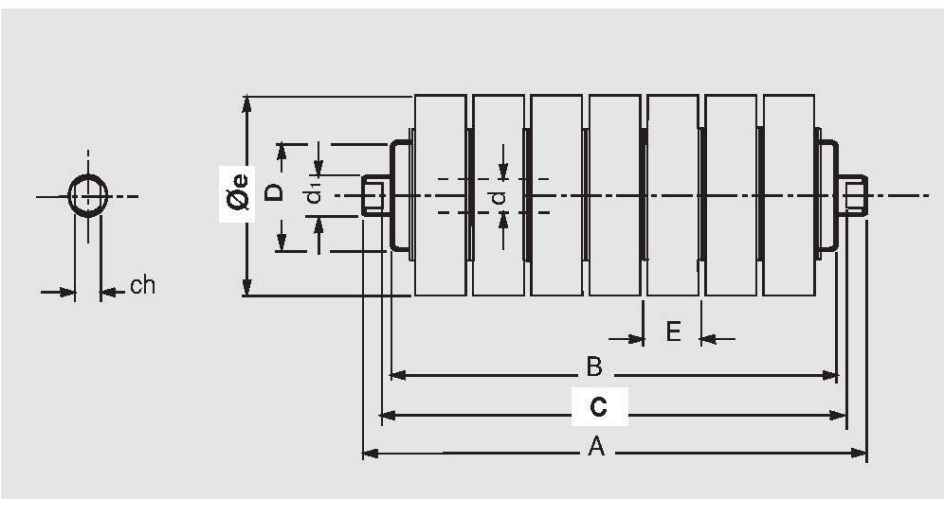

Figure 2 Impact roller PSV4,30F,159NA,473 dimensions 
Three impact rollers are placed in the troughing set (label A3P/55,1200,F22,H188, YA,R; manufacturer Rulmeca) made of steel profiles. The side rollers are inclined at an angle of , as it can be seen from the conveyor cross section, while the central roller is horizontal so it is located in the most unfavourable position in terms of load.

Cross sectional view of the shuttle belt conveyor T 3506 is given in Figure 3.

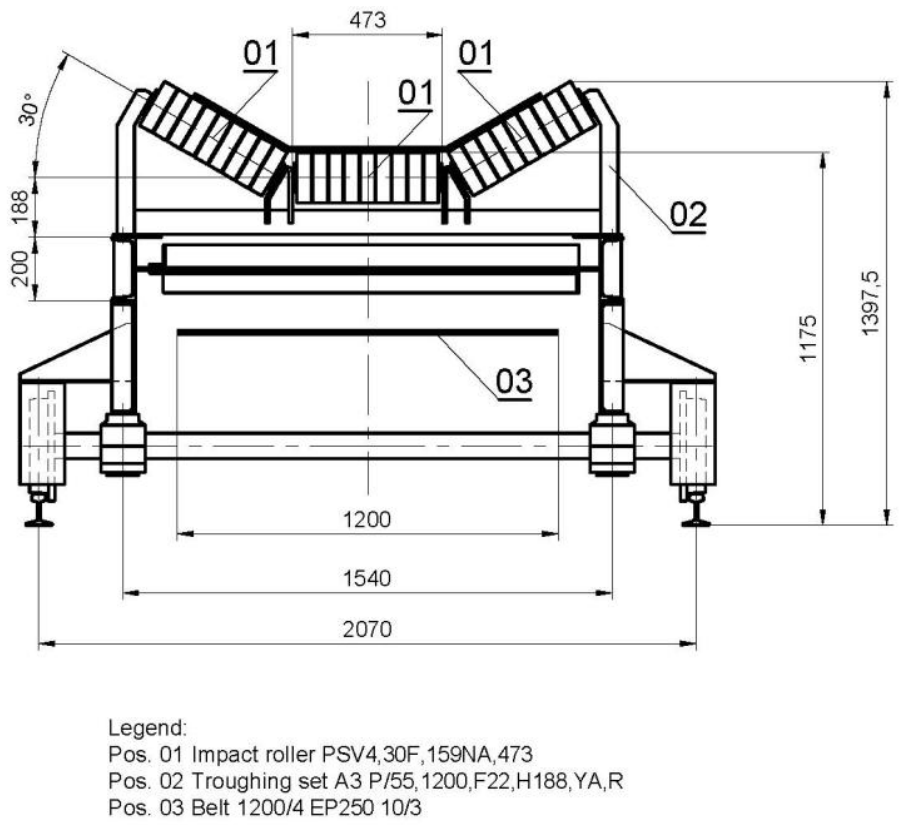

Figure 3 Cross section of shuttle belt conveyor T 3506

\section{CALCULATION OF IMPACT ROLLERS}

\subsection{Constant loading with uniform fine material}

1. Calculation of impact rollers according to this criterion is aimed for selection the impact roller of suitable capacity regarding the total load consisting of the impact force of material on one side, and on the other side consisting of the load of material and belt weight, and it is given

2. Impact force

3. Impact force on the central roller according to [2]. 
where:

$$
\begin{aligned}
& \text { - - belt load capacity } \\
& \text { - load fall height } \\
& \text { - participation factor of }
\end{aligned}
$$

roller under the highest stress for side rollers inclination angle of set

4. Static load on the carrying troughing hing set

6. Load on the roller carrying the highest force

Where are:

$$
\begin{aligned}
& \text { - spacing of carrying } \\
& \text { troughing sets } \\
& \text { - }- \text { mass of belt per linear } \\
& \text { meter } \\
& \text { - - belt load capacity } \\
& \text { - - belt speed }
\end{aligned}
$$

size of

[-] - impact factor for lump

the belt conveyor of and belt speed of

[-] - service factor of belt conveyor operation of over $16 \mathrm{~h} /$ day

[-] - environment factor for present abrasive or corrosive material

[-] - participation factor of ro-

ller under the highest stress for side rollers inclination angle of
7. Total load on the troughing set central roller

where:

- roller load capacity

for belt speed of

- and wor-

king life of

\subsection{Loading of material consisting of large lumps}

1. Calculation of impact rollers according to this criterion is aimed to check the bearings static load of selected roller compared with dynamic falling force during material fall, and it is given according to [2].

2. Dynamic falling force during material fall

where:

for $\quad$; prismatic shape of

lumps and material density of

- load fall height

- - constant of elastic-

city for impact rollers with rubber rings

- bearing static load

for bearing 6206 in $\mathrm{kg}$

\section{DISCUSSION OF CALCULATION}

The results obtained by calculation indicate that the selection of an impact roller primarily depends on the impact load value of the material falling on the belt of conveyor. 


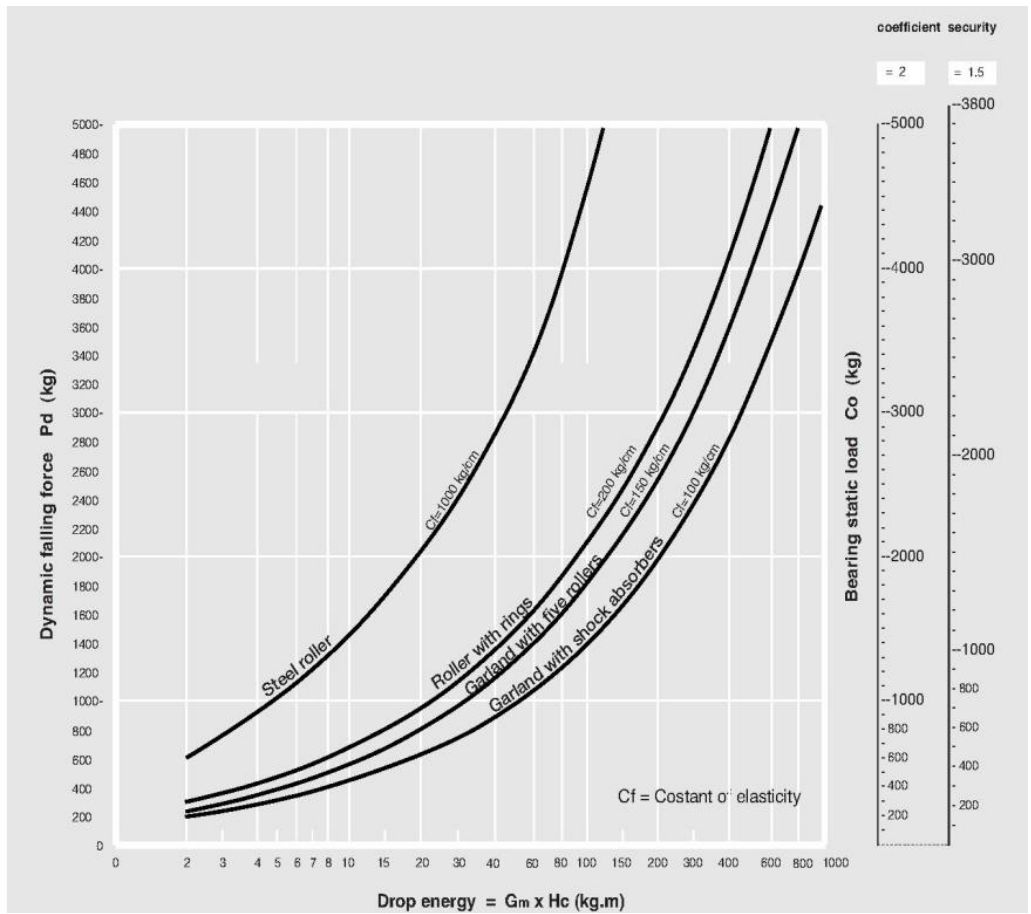

Figure 4 Diagram of relation between dynamic falling force of material fall and drop energy

In calculation by the first criterion the total load on the troughing set central roller is compared with the load capacity of the flat steel roller with diameter of $89 \mathrm{~mm}$ on which rubber rings are fitted. In the calculation by the second criterion, the required bearing static load is determined with coefficient of security 2 assuming that only one of two roller bearings can with-stand the total dynamic falling force of material fall. For simpler determination the dynamic falling force of material fall, there is a diagram in literature [2] given in Figure 4 that shows the relation between it and the drop energy expressed as a product for different cases of amorti-zation considering the required bearing static load with corresponding security coefficient.

\section{CONCLUSION}

As it can be seen from the calculation, the selected roller PSV4,30F,159NA,473 meets both criteria, i.e. at constant loading with uniform fine material and at loading of material consisting of large lumps.

Impact rollers selection is often done from the manufacturer catalogue data. On this occasion, it is necessary to analyze how the impact roller works in the given operating conditions, so this work may be a useful contribution in that sense.

\section{REFERENCES}

[1] Technical Design of Relocation the Crushing Plant from the North Mining District and Construction a New Transport System No. 3 for Ore of the 
South Mining District Deposit in the Copper Mine Majdanpek - Technical Mechanical Design of Installation the Primary Sieve with Stacker for Large Fraction Screening Product and Reversible Conveyor"; Mining and Metallurgy Institute Bor; Section MEGA; 2013 (in Serbian);

[2] Rollers and Components for Bulk Handling; Rulmeca Company Catalogue, Rulli Rulmeca S.p.A.; $4^{\text {th }}$ edition; July 2003.
[3] R. Rajković, R. Lekovski, B. Rajković, "Transportation Costs of Stacionary Conveyor for Overburden Transportation System of Veliki Krivelj copper Pit in Relation to Inclination of Bearing Rollers“, 39 ${ }^{\text {th }}$ International October Conference on Mining and Metallurgy, 07-10. October 2007, Soko Banja - Serbia. 


\begin{tabular}{ll}
\hline \hline INSTITUT ZA RUDARSTVO I METALURGIJU BOR & ISSN: 2334-8836 (Štampano izdanje) \\
UDK: 622 & ISSN: 2406-1395 (Online) \\
\hline \hline
\end{tabular}

UDK: $621.967 .2: 622(045)=163.41$

doi:10.5937/MMEB1504111R

Branislav Rajković, Zoran Ilić, Daniela Urošević*

\title{
IZBOR AMORTIZACIONIH ROLNI TRAKASTOG TRANSPORTERA ZA RUDU
}

\author{
Izvod \\ U ovom radu je, na primeru pokretnog reverzibilnog trakastog transportera za rudu T 3506 projek- \\ tovanog za potrebe površinskog kopa u Majdanpeku sa kapacitetom 1600 t/h, data metodologija pro- \\ računa amortizacionih rolni. \\ Analiza je urađ̄ena računskim putem prema uputstvima proizvođača firme "Rulmeca" i obuhvata \\ proveru statičkog $i$ dinamičkog opterećenja amortizacionih rolni. \\ Takođe su date tehnicke karakteristike amortizacionih rolni kao i njihov grafički prikaz. \\ Ključne reči: trakasti transporter za rudu, proračun amortizacionih rolni, tehničke karakteristike
}

\section{UVOD}

Na utovarnom delu trakastog transportera noseće rolne su pored opterećenja od težine materijala i od težine transportne trake opterećene i na udarno opterećenje od materijala koji pada na transportnu traku. Ovo udarno opterećenje neophodno je uzeti $u$ obzir pri izboru nosećih rolni na mestima gde se obavlja utovar materijala na traku.

Pokretni reverzibilni trakasti transporter za rudu T 3506 je pozicioniran iznad otvorenog sklada za rudu i projektovan je tako da se utovar materijala obavlja preko stacionarnog trakastog transportera T 3507, a istovar materijala se obavlja preko pogonskog ili zateznog bubnja u zavisnosti od smera kretanja trake transportera. Pri radu transportera on vrši translatorno kretanje kako bi se obavilo punjenje otvorenog sklada za rudu po celoj dužini. Kao posledica translatornog kretanja transportera i utovar materijala se obavlja po celoj njegovoj dužini što uslovljava izbor nosećih rolni kao amortizacionih.

Pokretni reverzibilni trakasti transporter za rudu T 3506 je izveden kao horizontalni, a noseće rolne su izvedene kao amortizacione i nalaze se u slogovima od po tri rolni u svakom slogu [1].

\section{TEHNIČKI OPIS AMORTIZACIONIH ROLNI}

Amortizacione rolne se sastoje od čelične rolne manjeg prečnika od nazivnog prečnika same rolne na koju su montirani gumeni prstenovi koji služe za amortizaciju pri padu materijala na traku.

Amortizaciona rolna (oznake PSV4,30F, 159NA,473; proizvođača Rulmeca) pripada seriji PSV rolni i sastoji se od omotača rolne, kućišta ležajeva, osovine, ležajeva, zaptivača i gumenih prstenova. Omotač rolne predstavlja obrađenu čeličnu cev za koju se zavaruju kućišta ležajeva. Kućišta ležajeva se izrađuju dubokim izvlačenjem od čelika sa nahnadnom mašinskom obradom tako da

\footnotetext{
* Institut za rudarstvo i metalurgiju Bor, branislav.rajkovic@irmbor.co.rs
} 
sa omotačem rolne čine jedan kompaktan sklop koji obezbeđuje dobro balansiranje rolne i koncentričnost elemenata sklopa. Osovina je od čelika, mašinski obrađena i na nju se montiraju prsteni kuglični jednoredi ležajevi 6206. Zaptivanje obuhvata spoljašnji štitnik, spoljašnju i unutrašnju sekciju. Zaptivanjem se onemogućava prodor neči- stoća sa spoljašnje strane (prašina, pesak, voda itd.), nečistoća sa unutrašnje strane (rđa, kondenzat) i takođe se osigurava podmazivanje ležajeva mašću. Sa spoljne strane omotača rolne montiraju se amortizacioni gumeni prstenovi. Ukupna masa rolne je 12,6 kg. Amortizaciona rolna u preseku data je na slici 1 .

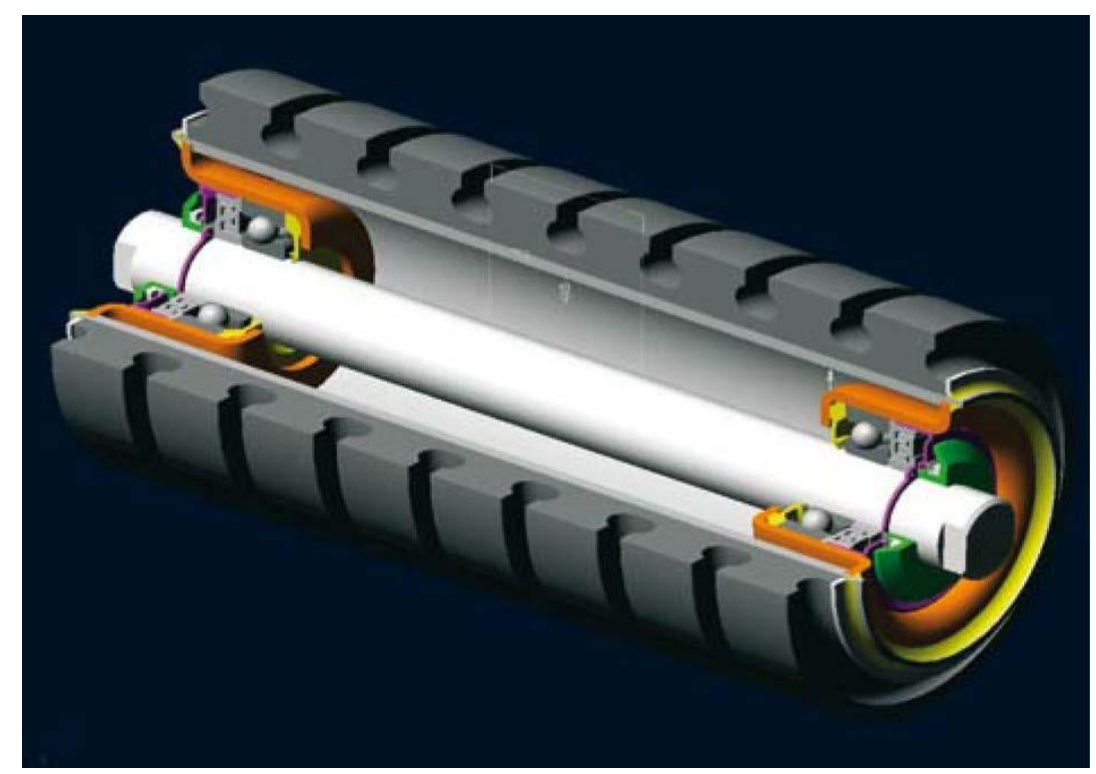

S1. 1. Amortizaciona rolna u preseku

Dimenzije amortizacione rolne PSV 4,30F,159NA,473 su date na slici 2.

$$
\begin{aligned}
& \varnothing e=159 \mathrm{~mm} \\
& D=89 \mathrm{~mm} \\
& d=30 \mathrm{~mm} \\
& d_{l}=30 \mathrm{~mm} \\
& c h=22 \mathrm{~mm} \\
& A=497 \mathrm{~mm} \\
& B=465 \mathrm{~mm} \\
& C=473 \mathrm{~mm} \\
& E=50 \mathrm{~mm}
\end{aligned}
$$

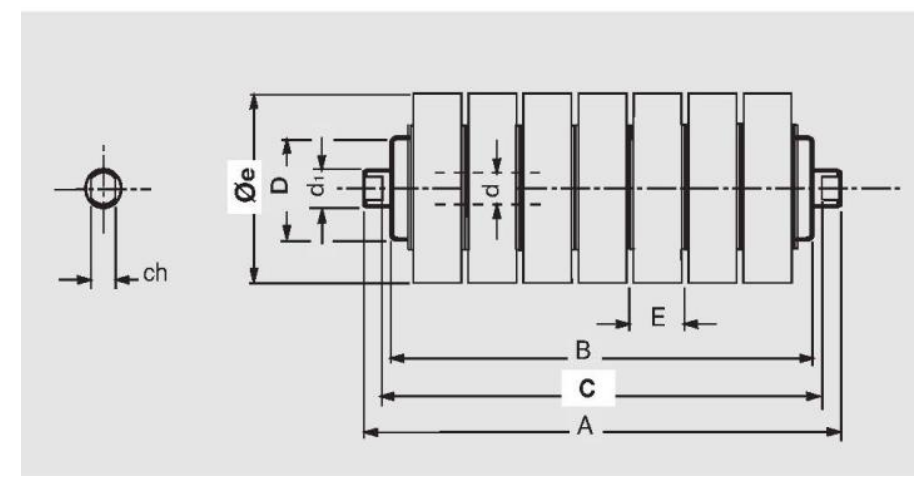

S1. 2. Dimenzije amortizacione rolne PSV4,30F,159NA,473 
U nosećem slogu (oznake A3P/55,1200, F22, H188,YA,R; proizvođača Rulmeca) izrađenom od čeličnih profila nalaze se tri amortizacione rolne. Bočne rolne su nagnute pod uglom , kao što se vidi u poprečnom preseku transportera, dok je centralna rolna horizontalna tako da se ona nalazi u najnepovoljnijem položaju u smislu opterećenja.

Prikaz poprečnog preseka pokretnog reverzibilnog trakastog transportera T 3506 dat je na slici 3 .

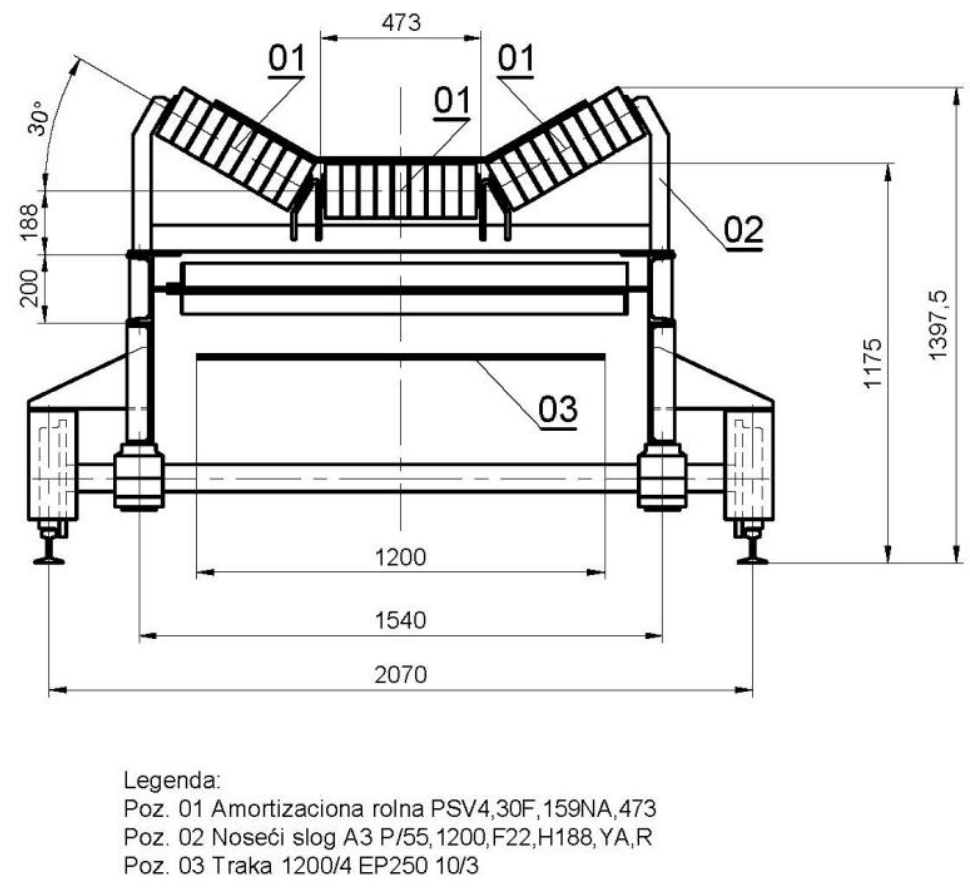

Sl. 3. Poprečni presek pokretnog reverzibilnog trakastog transportera T 3506

\section{PRORAČUN AMORTIZACIONIH ROLNI}

\subsection{Konstantan utovar sa ravnomernim} sitnim materijalom

1. Proračun amortizacionih rolni prema ovom kriterijumu ima za cilj izbor amortizacione rolne odgovarajuće nosivosti prema ukupnom opterećenju od udarne sile materijala sa jedne strane i opterećenju od težine materijala i trake sa druge strane $i$ dat je

2. Udarna sila

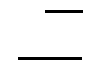

3. Udarna sila na centralnu rolnu prema [2]. 
gde su:

- - kapacitet transportera

- visina pada tereta

- uticajni faktor rolne pod najvećim opterećenjem za ugao nagiba bočnih rolni

4. Statičko opterećenje na noseći slog

5. Dinamičko opterećenje na noseći $\operatorname{slog}$

6. Opterećenje na rolnu koja nosi najveću silu

gde su:

$$
\begin{aligned}
& \text { - rastojanje nosećih } \\
& \text { slogova } \\
& \text { - - masa trake po dužnom } \\
& \text { metru } \\
& \text { - - kapacitet transportera } \\
& \text { - - brzina trake } \\
& \text { - faktor udara za veličinu }
\end{aligned}
$$

komada i brzinu trake

trakastog transportera

- radni faktor za rad trakastog transportera preko $16 \mathrm{~h}$ dnevno

- faktor radne sredine za prisutan abrazivni ili korozivni materijal

- uticajni faktor rolne pod najvećim opterećenjem za ugao nagiba bočnih rolni
7. Ukupno opterećenje na centralnu rolnu nosećeg sloga

gde je:

zinu trake - nosivost rolne za br-

\subsection{Utovar sa materijalom koji se sastoji od krupnih komada}

1. Proračun amortizacionih rolni prema ovom kriterijumu ima za cilj proveru statičke nosivosti ležajeva izabrane rolne $u$ odnosu na dinamičku silu pri padu materijala i dat je prema [2].

2. Dinamička sila pri padu materijala

gde su:

- masa komada materi-

jala za ; prizmatični oblik

komada i stvarnu gustinu materijala

-visina pada tereta

- - koeficijent elastično-

sti amortizacionih rolni za rolne sa gumenim prstenovima

žaja 6206 u kg

- statička nosivost le-

\section{DISKUSIJA PRORAČUNA}

Proračunom dobijeni rezultati pokazuju da izbor amortizacione rolne zavisi pre svega od veličine udarnog opterećenja od materijala koji pada na transportnu traku. 


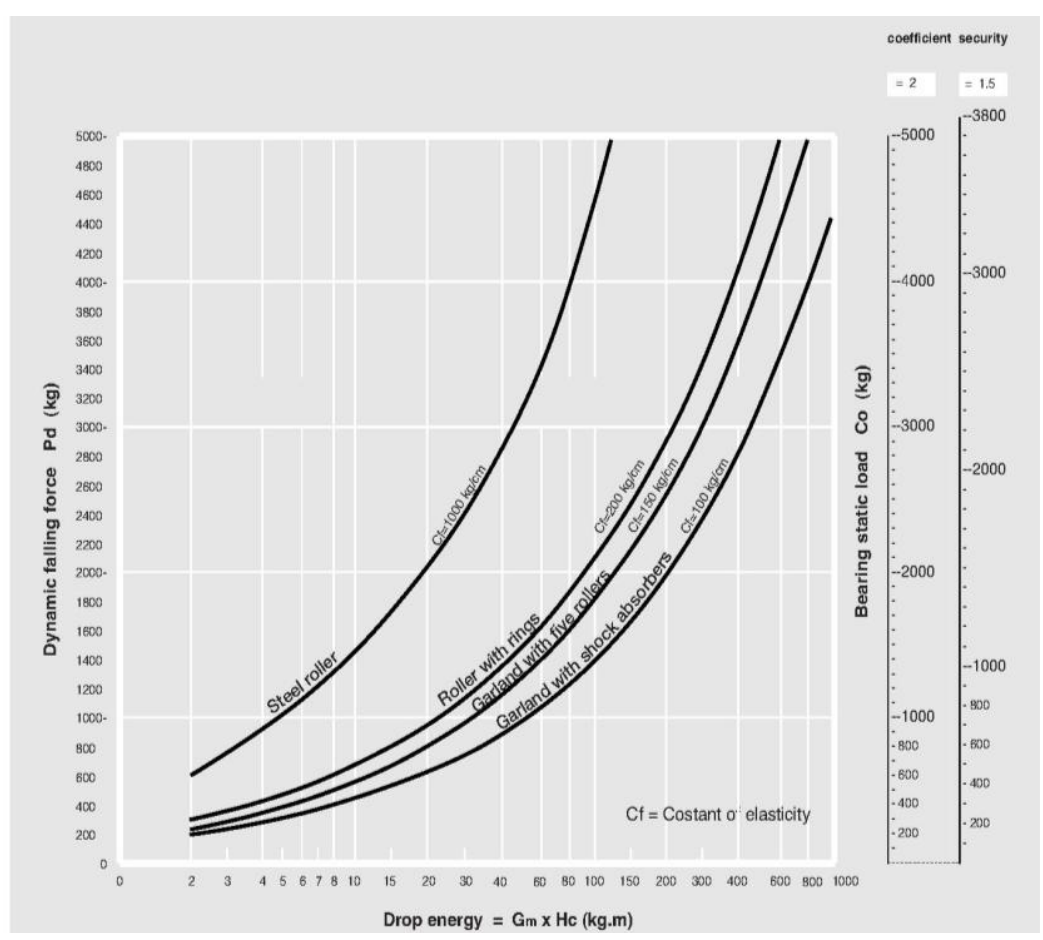

S1. 4. Dijagram zavisnosti dinamičke sile od pada materijala od energije pada

Pri proračunu po prvom kriterijumu se ukupno opterećenje na centralnu rolnu nosećeg sloga upoređuje se nosivošću glatke čelične rolne prečnika $89 \mathrm{~mm}$ na koju se montiraju gumeni prstenovi. Pri proračunu po drugom kriterijumu se potrebna statička nosivost ležajeva usvaja sa stepenom sigurnosti 2 odnosno pretpostavlja se da celokupnu dinamičku silu od pada materijala može da primi samo jedan od dva ležaja rolne. Za jednostavnije određivanje dinamičke sila od pada materijala u literaturi [2] se daje dijagram dat na crtežu 4 . u kome se ona daje u zavisnosti od energije pada kao proizvoda za različite slučajeve amortizacije uzimajući u obzir potrebnu statičku nosivost ležajeva sa odgovarajućim stepenom sigurnosti.

\section{ZAKLJUČAK}

Kao što se iz proračuna vidi izabrana rolna PSV4,30F,159NA,473 zadovoljava po oba kriterijuma tj. pri konstantnom utovaru sa ravnomernim sitnim materijalom i pri utovaru sa materijalom koji se sastoji od krupnih komada.

Izbor amortizacionih rolni često se vrši iz kataloških podataka proizvođača. Tom prilikom je potrebno analizirati kako se amortizaciona rolna ponaša $u$ datim radnim uslovima, te ovaj rad može biti koristan doprinos u tom smislu.

\section{LITERATURA}

[1] „Tehnički projekat preseljenja drobiličnog postrojenja sa Severnog revira i izgradnje novog transportnog sistema br. 3 za rudu ležišta Južni Revir 
u Rudniku bakra Majdanpek-Tehni-čki mašinski projekat ugradnje primarnog sita sa odlagališnim transporterom za nadrešetni proizvod i reverzibilnim transporterom"; Institut za rudarstvo i metalurgiju Bor; odeljenje MEGA; 2013.

[2] Katalog firme Rulmeca: „Rollers and components for bulk handling"; Rulli Rulmeca S.p.A.; 4. izdanje; jul 2003.
[3] R. Rajković, R. Lekovski, B. Rajković, "Troškovi transporta stacionarnim transporterom transportnog sistema jalovine površinskog kopa bakra "Veliki Krivelj" u funkciji nagiba nosećih valjaka", 39. Međunarodno oktobarsko savetovanje o rudarstvu i metalurgiji, 07-10 oktobar 2007, Soko Banja - Srbija. 